\title{
ANALISA TINGKAT UPAH PEKERJA WANITA DI PABRIK ROKOK (Study Pada Perusahaan Rokok "EMPAT SAUDARA ABADI" di Desa Jambi Kecamatan Baron, Kabupaten Nganjuk)
}

\author{
Oleh: \\ Ery Kisworo \\ Fakultas Ekonomi dan Bisnis Universitas Muhammadiyah Malang
}

\begin{abstract}
The purpose of this study was to find out how much the level of wages of women workers in the factory cigarette "Empat Saudara Abadi" in the village of Jambi District of Baron Nganjuk, in this study the author took the hypothesis is suspected that there is influence between the level of education, age, length of service and number of dependency family against wage levels. The technique used is by using a percentage formula and using multiple linear regression, using the $\mathrm{F}$ test and $\mathrm{t}$ test and classical assumption. Based on the empirical results mentioned that variable levels of education, longer working, and the number of family dependents burden, affect the level of wages.
\end{abstract}

Keywords: Education Level, Age, Old Work, Number of Dependents Family, Multiple Linear Regression

\begin{abstract}
ABSTRAK
Tujuan dari penelitian ini adalah Untuk mengetahui seberapa besar tingkat upah pekerja wanita dipabrik rokok "Empat Saudara Abadi" di Desa Jambi Kecamatan Baron Kabupaten Nganjuk, dalam penelitian ini penulis mengambil hipotesa diduga bahwa ada pengaruh antara tingkat pendidikan, usia, lama bekerja dan jumlah beban tanggungan keluarga terhadap tingkat upah. Teknik yang digunakan adalah dengan menggunakan rumus prosentase dan menggunakan regresi linier berganda, dengan menggunakan uji f dan uji t serta asumsi klasik. Berdasarkan hasil empiris menyebutkan bahwa variable tingkat pendidikan, lama bekerja, dan jumlah beban tanggungan keluarga, berpengaruh terhadap tingkat upah .
\end{abstract}

Kata Kunci : Tingkat Pendidikan, Usia, Lama Bekerja, Jumlah Tanggungan Keluarga, Regresi Linear Berganda

\section{PENDAHULUAN}

Kondisi perekonomian yang terus meningkat diIndonesia ini semakin meningkat sehingga memunculkan penganguran yang cukup banyak diIndonesia. Tetapi jumlah penduduk yang banyak bukan masalah jika didukung dengan ekonomi negara yang dapat menyerap pertumbuhan angkatan kerja, sebab penduduk yang besar berfungsi juga sebagai tenaga kerja. Di satusisi adalah faktor produksi yang dapat neningkatkan pendapatan domestik bruto (PDB) dan satu sisi lainya adalah konsumen yang akan menyerap hasil output yang dihasilkan. 
Konsep pembangunan sering dikaitkan dengan industrialisasi karena dianggap mempunyai pengertian yang sama, hal ini mempunyai arti bahwa pembangunan ekonomi menekankan pada semua sektor. Baik itu sektor industri, pertanian, maupun sektor lain. Dari berbagai sektor, sektor industri merupakan sektor yang paling diprioritaskan, sebab dianggap mampu mendorong pembangunan secara cepat. Bahkan kemajuan dan peran yang besar dari industri dalam perekonomian yang sering dijadikan tolak ukur dalam kemajuan suatu bangsa.

Pembangunan merupakan suatu kegiatan menuju kepada tata kehidupan dan kehidupan yang lebih baik dan sesuai dengan tujuan pembangunan nasional menurut GBHN tahun 1978 adalah: "Bahwa pembangunan nasional bertujuan untuk meningkatkan masyarakat adil dan makmur yang merata material maupun spiritual berdasarkan pancasila dan UUD 1945.

Adapun maksud pembangunan nasional di atas bertujuan untuk membangun manusia Indonesia seutuhnya yang membawa konsekuensi kepada setiap warga negara untuk turut berpartisipasi aktif dalam proses pembangunan yang sedang berlangsung sekarang ini. Dengan demikian mengingat wanita adalah subyek dan sekaligus obyek pembangunan, maka dituntut untuk ikut serta berpartisipasi dalam pembangunan.

Aktor dan subyek pembangunan tidak hanya didominasi oleh peran pria aja tetapi juga menyangkut peranan wanita yang mempunyai derajat atau kesempatan yang sama dan semua itu akan tergantung pula pada para wanita untuk bisa tampil sebagai aktor pembangunan. Peranan wanita dalam pembangunan mempunyai arti yang penting bagi keberhasilan dan kelancaran, baik dalam pembinaan keluarga maupun generasi muda untuk menciptakan manusia Indonesia seutuhnya. Untuk mewujudkan hal tersebut maka perlu adanya usaha-usaha guna meningkatkan pengetahuan, keterampilan serta kepemimpinan wanita.

Level atau tingkat pendapatan nasional mencerminkan keberhasilan perekonomian Negara. Semakin 
tinggi level pendapatan nasional semakin tinggi pula tingkat kesejahteraan penduduk dalam suatu Negara. Kesejahteraan penduduk ini dapat dilihat dari peningkatan standart hidup penduduk terutama yang berhubungan dengan tersedianya bahan makanan dan fasilitas-fasilitas yang ada seperti sandang, pangan dan perumahan dan mencakup penyediaan jasa umum pokok seperti kesehatan dan pendidikan.

Dari proses pembangunan masyarakat itu ditujukan pada tiga sasaran yaitu meningkatkan pemerataan kebutuhan pokok, meningkatkan penghasilan penyediaan lapangan kerja yang memadai dan pendidikan yang lebih baik serta memperluas jangkauan ekonomi dan social rakyat. Demikian pula pembangunan yang dilaksanakan di Indonesia ditujukan untuk mencapai tiga sasaran tersebut, secara ringkas tujuan ini di nyatakan untuk mewujudkan masyarakat yang adil dan makmur.

$$
\text { Salah satu tujuan }
$$
pembangunan yang dilakukan oleh pemerintah adalah untuk meningkatkan kesejahteraan masyarakat dimana tujuan tersebut tidak lepas dari upaya pemenuhan kebutuhan pokok. Selain itu pemerintah telah mencanangkan program pemerataan pembangunan dan hasilnya dengan tujuan perbaikan juga peningkatan kesejahteraan rakyat.

Berdasarkan kenyataan tingkat pendapatan suatu keluarga yang masih relative rendah menyebabkan para wanita ikut mencari nafkah sebagai tambahan penghasilan suami untuk mencukupi pemenuhan kebutuhan sehari-hari sehingga peranan wanita selain mereka berperan sebagai ibu rumah tangga mereka juga sebagai tenaga kerja.

Sementara orang memandang bahwa wanita hanya berperan dalam kegiatan reproduksi tidak sesuai lagi dibanyak tempat termasuk dalam dunia sedang berkembang. Dalam hal ini wanita selain bertanggung jawab dengan pekerjaan rumah tangga, mereka juga ikut pula menanggung beban untuk mencari nafkali demi kelangsungan hidup keluarga.

Hal tersebut menyebabkan masalah peranan wanita timbul baik karena ketidakmampuan secara 
pribadi untuk menyesuaikan diri dengan perubahan masyarakat dengan segala tatanan sosialnya, dengan demikian masalah peranan wanita rnerupakan bagian yang tak terpisahkan dan masalah nasional pada umumnya seperti masalah ekonomi, sosial, politik dan budaya.

Dari kenyataan diatas, peranan pekerja wanita biasanya jauh lebih kecil. Mayoritas wanita bekerja di sektor formal menduduki posisi yang kurang penting. Hal ini memang sering dikaitkan dengan kemampuan wanita yang lebih terbatas, yang seringkali merupakan cerminan dari pendidikannya. Alasan lain yang sering pula dikemukakan adalah wanita hanya cocok bagi pekerjaan yang feminine atau pekerjaan yang berkaitan dengan nalurinya dalam peran sebagai ibu rumah tangga atau mitra pembentu laki-laki. (Barry, 1989 seperti dikutip oleh Crysanti Hasibuan-Sedyono dalam Gardier, 1994; 214).

Tenaga kerja wanita sebagai salah satu dari factor produksi, yang memiliki peranan sangat penting dalam perusahaan rokok. Oleh karena sebagian besar dari lantai dasar produksi di perusahaan rokok memerlukan kerapian yang dimiliki para tenaga kerja wanita.

Dengan adanya dunia usaha yang semakin berkembang dewasa ini, banyak perusahaan-perusahaan baru, sehingga persaingan antara perusahaan sejenis semakin tajam dalam menduduki pasar. Tingginya tingkat pertumbuhan penduduk dari tahun ke tahun sangat mempengaruhi besarnya jumlah tenaga kerja yang ada dan jumlah ketersediaan lapangan kerja yang sangat terbatas, sedangkan permintaan tenaga kerja (kesempatan kerja) pertumbuhannya lebih lambat sehingga keadaan pasar tenaga kerja mengalami ketimpangan, sementara pertambahan penduduk ini tentu memerlukan pertumbuhan dalam permintaan barang dan jasa.

Dengan demikian terdapat ketimpangan pasar tenaga kerja antara permintaan tenaga kerja dan penawaran tenaga kerja, dimana masih besar tenaga kerja yang ada. Hal ini menimbulkan semakin banyaknya tingkat pengangguran.

Salah satu penyebab kenaikan angkatan wanita bekerja adalah kemiskinan yang mendorong wanita bekerja untuk memperoleh upah atau 
pendapatan. Ini adalah gambaran dimana anggota keluarga miskin termasuk wanitanya tidak dapat hidup dalam keadaan menganggur. Suatu rumah tangga semakin dihimpit kemiskinan semakin berat tekanan yang memaksa mereka untuk mencari kerja produktif meskipun dengan imbalan yang rendah.

Hal ini tentunya harus diantisipasi dan upaya menciptakan lapangan kerja baru bagi para tenaga kerja dan peran serta dari seluruh warga negara Indonesia secara aktif tanpa terkecuali peran serta wanita untuk masuk dalam dunia kerja, demi kebaikan ekonomi keluarga dan mengurangi tingkat pengangguran untuk mencapai suatu kesejahteraan.

Disini wanita bekerja disebabkan karena adanya beban tanggungan keluarga yang banyak, dan tuntutan ekonomi yang semakin rendah menyebabkan seorang pekerja wanita bekerja pada perusahaan rokok "Empat Saudara Abadi" yang sekiranya bisa meringankan beban tanggungan suami dan meringankan beban taggungan keluarga mereka. Dengan upah atau pendapatan yang sudah mereka terima, hal itu bisa meringankan beban keluarga mereka dan bisa menciptakan keluarga yang scjahtcra. Dan hal ini dapat dilihat pada pekerja wanita yang bekerja pada perusahaan rokok "Empat Saudara Abadi" di Desa Jambi Kec. Baron Kab. Nganjuk.

\section{METODE PENELITIAN}

Penelitian ini dilakukan pada perusahaan rokok "Empat Saudara Abadi” di Desa Jambi Kecamatan Baron Kabupaten Nganjuk. Dan penelitian ini difokuskan pada karakteristik pekerja wanita yang didasarkan pada tingkat pendidikan, usai, lama bekerja dan jumlah beban tanggungan keluarga dan difokuskan pada pengaruh karakteristik pekerja wanita terdapat tingkat upah pada perusahaan rokok "Empat Saudara Abadi” di Desa Jambi Kecamatan Baron Kabupaten Nganjuk. Alasan pemilihan lokasi ini, karena pada perusahaan rokok ini mempunyai tenaga kerja wanita yang cukup banyak yaitu berjumlah 416 .

Sumber data dalam penelitian ini menggunakan data primer. Karena data yang akan digunakan bersifat observasi yang mana penelitian berusaha mencari data 
mengenai karakteristik pekerja wanita pada perusahaan rokok "Empat Saudara Abadi" di Desa Jambi Kecamatan Baron Kabupaten Nganjuk dan pengaruh pengaruh karakteristik pekerja wanita terhadap tingkat upah pada perusahaan rokok "Empat Saudara Abadi" di Desa Jambi Kecamatan Baron Kabupaten Nganjuk

Agar data-data penelitian ini dapat memberikan hasil yang sesuai dengan teori dan setelah data terkumpul sesuai dengan kebutuhan. Selanjutnya melakukan analisa terhadap hal-hal yang menimbulkan masalah perusahaan. Metode analisa yang dilakukan adalah menggunakan analisa regresi linier berganda.

$$
\begin{aligned}
Y= & a+b_{1} X_{1}+b_{2} X_{2}+b_{3} X_{3}+ \\
& b_{4} X_{4}+e
\end{aligned}
$$

\section{Dimana:}

$$
\begin{aligned}
& \mathrm{Y}=\text { Tingkat Upah (Rp) } \\
& \mathrm{X}_{1}=\text { Tingkat Pendidikan (Th) } \\
& \mathrm{X}_{2}=\text { Usia (Th) } \\
& \mathrm{X}_{3}=\text { Lama Bekerja (Th) } \\
& \mathrm{X}_{4}=\text { Beban Tanggungan } \\
& \quad \text { Keluarga (Org) } \\
& \mathrm{b}_{1}, \mathrm{~b}_{2}, \mathrm{~b}_{3}, \mathrm{~b}_{4}=\text { Taksiran parameter }
\end{aligned}
$$

\section{PEMBAHASAN}

Berbagai macam kebutuhan yang muncul mendorong manusia untuk memenuhinya. Salah satu cara untuk memenuhi kebutuhan tersebut adalah dengan bekerja. Hal ini pula yang dilakukan oleh para wanita Desa Jambi Kec. Baron. Mereka menawarkan tenaganya pada perusahaan rokok yang ada di Desa Jambi yaitu perusahaan rokok "Empat Saudara Abadi" dan memperoleh imbalan atau upah dari perusahaan tersebut sebagai harga dari tenaga mereka.

Sempitnya lapangan pekerjaan yang ada di desa Jambi mendorong para wanitanya untuk mencari pekerjaan di kota. Perusahaan rokok "Empat Saudara Abadi" merupakan salah satu faktor penarik bagi para tenaga kerja wanita yang mencari pekerjaan, karena perusahaan rokok tersebut mampu menciptakan lapangan kerja dan menyerap tenaga kerja wanita dengan jumlah yang cukup besar. Terbukti ada 360 orang wanita desa Jambi bekerja pada perusahaan rokok tersebut. dari 360 orang wanita tersebut telah diambil 50 orang untuk menjadi obyek penelitian guna memperoleh data.

Hasil pengumpulan data dari 50 orang responden yang diperoleh melalui penelitian lapangan di desa Jambi Kec. Baron Kab. Nganjuk diketahui sebagian 
besar responden berusia 20 tahun ke atas dengan status perkawinan sudah menikah yaitu sebanyak 35 orang responden dan yang berusia kurang dari 20 tahun belum menikah yaitu sebanyak 2 orang responden dan sisanya adalah janda yaitu sebanyak 3 orang responden terhadap faktor tingkat pendidikan, tingkat upah, jumlah beban tanggungan keluarga, usia, dan lama bekerja dapt diuraikan sebagai berikut:

\section{Tingkat Pendidikan}

Tingkat pendidikan dari responden secara terperinci dapat dilihat pada label di bawah ini:

Tabel 1. Prosentase Distribusi Responden Menurut Tingkat Pendidikan

\begin{tabular}{clcc}
\hline No & Tingkat Pendidikan & Jumlah (orang) & Prosen (\%) \\
\hline 1 & Tamat SD & 19 & $38 \%$ \\
\hline 2 & Tamat SMP & 26 & $52 \%$ \\
\hline 3 & Tamat SMA & 5 & $10 \%$ \\
\hline & Jumlah & 50 & $100 \%$
\end{tabular}

\section{Sumber : Diolah dari data primer}

Tabel 1 di atas menunjukkan bahwa dari 50 orang responden kelompok tingkat pendidikan responden terbanyak adalah tamat SMP yaitu sebanyak 26 orang atau $52 \%$ dengan jenis pekerjaan 15 orang bagian pengepakan dan sisanya 11 orang bagian giling. Urutan berikutnya dijumpai pada kelompok responden dengan pendidikan tamat SD yaitu sebanyak 19 orang atau $38 \%$ dan jenis pekerjaannya semuanya atau 19 orang responden bekerja pada bagian gunting.

Untuk kelompok yang terakhir adalah tingkat pendidikan tamat SMA dimana hanya ada 5 orang responden atau hanya sebesar $10 \%$ dan jenis pekerjaan mereka adalah 2 orang pada bagian giling dan 3 orang sebagai mandor.

\section{Lama Bekerja}

Tabel 2. Prosentase Distribusi Responden Menurut Lama Bekerja

\begin{tabular}{cccc}
\hline No & Lama Bekerja & Jumlah (orang) & Prosen (\%) \\
\hline 1 & $2-3$ Tahun & 12 & $24 \%$ \\
\hline 2 & $4-5$ Tahun & 22 & $44 \%$ \\
\hline
\end{tabular}




\begin{tabular}{rlcc}
\hline 3 & 6 Tahun & 8 & $16 \%$ \\
\hline 4 & $>$ 6 Tahun & 8 & $16 \%$ \\
\hline & Jumlah & 50 & $100 \%$
\end{tabular}

Sumber : Diolah dari data primer

Dari data di atas memberikan fasilitas yang menunjukkan bahwa lamanya menunjang kegiatan para buruh.

responden bekerja biasaya dialami Ternyata jenis pekerjaan oleh responden yang bekerja sebagai pekerja atau karyawan. Responden yang paling lama bekerja adalah ratarata 4-5 tahun yaitu sebanyak 22 orang atau $44 \%$ sedangkan mereka pada umumnya mempunyai latar belakang pendidikan yang sama yaitu pendidikan SD dan SLTP, tentunya mereka tidak mempunyai keterampilan selain di pabrik rokok Empat Saudara Abadi dan mereka enggan berpindah ke perusahaan lainnya, alasannya karena pihak perusahaan telah sebagai karyawan di perusahaan rokok "Empat Saudara Abadi" Jambi-Baron akan berpengaruh terhadap ketrampilan yang mereka miliki serta akan berpengaruh terhadap pendapatan keluarga, sebab responden bekerja cukup lama, sehingga dapat meningkatkan pendapatan keluarga. Untuk lebih jelasnya dapat digambarkan sebagai berikut:

Jumlah Beban Tanggungan Keluarga

Tabel 3. Prosentase Distribusi Responden Menurut jumlah Beban Tanggungan Keluarga

\begin{tabular}{cccc}
\hline No & \multicolumn{1}{c}{$\begin{array}{c}\text { Jumlah Tanggungan } \\
\text { Keluarga }\end{array}$} & Jumlah (orang) & Prosen (\%) \\
\hline 1 & 2 orang & 5 & $10 \%$ \\
\hline 2 & 3 orang & 20 & $40 \%$ \\
\hline 3 & 4 orang & 17 & $34 \%$ \\
\hline 4 & $>4$ orang & 8 & $16 \%$ \\
\hline & Jumlah & 50 & $100 \%$ \\
\hline
\end{tabular}

Sumber : Diolah dari data primer 
Dari sejumlah responden yang diteliti ada $40 \%$ atau 20 orang responden yang memiliki jumlah beban tanggungan keluarga sedang yaitu 3 orang yang terdiri dari 2 anak dan 1 orang keluarga yang hidupnya di tanggung oleh responden. Untuk jumlah beban tanggungan keluarga 4 orang ada $34 \%$ atau 17 orang responden dengan jumlah anak sebanyak 2 orang dan 2 orang yang menumpang dan hidupnya ditanggung oleh responden. Untuk jumlah beban tanggungan keluarga lebih dari 4 orang adalah sebesar $16 \%$ atau 8 orang responden, dengan jumlah tanggungan 3 anak dan 2 orang keluarga yang ditanggung hidupnya. Sedangkan untuk jumlah beban tanggungan keluarga yang paling sedikit dimiliki oleh 5 orang responden, dengan jumlah beban tanggungan keluarga 2 orang tuanya saja dan hanya ada 1 anak dan 1 orang yang hidupnya ditanggung responden dan tidak ada keluarga yang hidupnya ditanggung oleh responden adalah sejumlah $10 \%$. Untuk lebih jelasnya dapat digambarkan sebagai berikut:

\section{Golongan Umur}

Tabel 4. Prosentase Distribusi Responden Menurut Golongan Umur

\begin{tabular}{llcc}
\hline No & \multicolumn{1}{c}{ Golongan Umur } & Jumlah (orang) & Prosen (\%) \\
\hline 1 & $<20$ tahun & 2 & $4 \%$ \\
\hline 2 & $20-30$ tahun & 38 & $76 \%$ \\
\hline 3 & $30-40$ tahun & 8 & $16 \%$ \\
\hline 4 & $40-50$ tahun & 2 & $4 \%$ \\
\hline & Jumlah & 50 & $100 \%$ \\
\hline
\end{tabular}

Sumber : Diolah dari data primer

Dari label di atas dapat dilihat bahwa kebanyakan tenaga kerja wanita yang bekerja pada perusahaan rokok "Empat Saudara Abadi" Baron adalah para tenaga kerja wanita yang berumur 20-30 tahun yaitu sebesar $76 \%$ atau 38 orang dimana pada umur ini merupakan umur dimana tenaga kerja masih dalam usia produktif yang banyak memiliki beban tanggungan keluarga, sedangkan yang berumur 30-40 tahun berjumlah $16 \%$ atau 8 orang responden, sedangkan yang berumur 40-50 tahun berjumlah $4 \%$ atau 2 orang responden. Walaupun sudah berumur tua mereka masih bekerja di perusahaan rokok tersebut, hal itu disebabkan karena 
adanya tuntutan ekonomi yang meningkat dan adanya jumlah beban tanggungan keluarga yang semakin banyak, sehingga mereka ingin sekali bekerja industri rokok yang dianggap masih menjanjikan untuk sebagai tambahan untuk memenuhi kebutuhan hidup keluarganya dimana upahnya lebih dari sektor yang lain. Untuk lebih jelasnya dapat digambarkan sebagai berikut:

\section{Tingkat Upah}

Tabel 5. Prosentase Distribusi Responden Menurut Tingkat Upah/Minggu

\begin{tabular}{cccc}
\hline No & Tingkat Upah (minggu) & Jumlah (orang) & Prosen (\%) \\
\hline 1 & $50.000-75000$ & 9 & $18 \%$ \\
\hline 2 & $75.000-100.000$ & 25 & $50 \%$ \\
\hline 3 & $100.000-125.000$ & 8 & $16 \%$ \\
\hline 4 & $125.000-150.000$ & 8 & $4 \%$ \\
\hline & Jumlah & 50 & $100 \%$
\end{tabular}

Sumber : Diolah dari data primer

$$
\text { Dari hasil pengisian }
$$

kuesioner 50 orang responden mengenai tingkat upah yang mereka terima dari Perusahaan Rokok sebagai harga dari tenaga mereka ternyata berbeda-beda antara responden satu dengan responden yang lainnya, antara jenis pekerjaan yang satu dengan jenis pekerjaan yang lain. Upah yang diterima responden dalam penelitian ini diterima per-minggu, dengan upah terbanyak terdapat pada kelompok tingkat upah berkisar antara Rp 75.000 - Rp 100.000 untuk 25 orang responden atau $50 \%$, dari 25 responden, 22 responden bekerja pada bagian gunting dan giling dengan upah $\mathrm{Rp}$ 9000 per 1000 linting atau Rp 54.000 per- minggu, kemudian sisanya 3 orang responden bekerja pada bagian pengepakan dengan upah Rp 6.000 per bal dan dikalikan dengan jumlah produksi yang dihasilkan dalam 1 hari untuk 1 minggu, untuk kelompok responden berikutnya yaitu dengan tingkat upah sebesar Rp 100.000Rp 125.000 untuk 8 orang responden atau 16\%, dimana untuk 2 orang responden bekerja pada bagian giling, 5 orang responden bekerja pada bagian 
pengepakan, dan sisanya 1 orang responden bekerja pada bagian gunting. Untuk bagian giling dan pengepakan tingkat upah/ pendapatan disesuaikan dengan hasil produksi yang dihasilkan dalam per-hari dikalikan dengan 1 minggu. Urutan berikutnya merupakan kelompok responden dengan tingkat upah yang tertinggi yaitu antara Rp $125.000 \quad-R p$ 150.000 perminggu dengan jumlah responden 8 orang atau $16 \%$, dimana 3 orang responden bekerja pada bagian mandor, dan 5 orang repsonden bekerja pada bagian pengepakan. Adapun kelompok responden dengan tingkat upah yang rendah yaitu antara $\mathrm{Rp}$ 50.000 - Rp 75.000 perminggu dengan jumlah responden 9 orang responden atau $18 \%$, dimana 3 orang responden bekerja pada bagian pengepakan, 4 orang responden lagi bekerja pada bagian giling dan sisanya 2 orang bekerja pada bagian gunting, upah mereka lebih sedikit disbanding dengan responden yang lain dikarenakan lama bekerja mereka masih belum lama dibandingkan dengan yang lain. Tingkat upah tersebut tentunya berbeda antara responden satu dengan yang lain, sedangkan dengan pendapatan yang diperoleh responden tiap minggunga tersebut, maka keadaan ekonomi keluarga lebih meningkat dibandingkan dengan responden sebelum bekerja di perusahaan rokok tersebut.

\section{Regresi Linier Berganda}

Berdasarkan hasil estimasi regresi yang tertuang pada tabel di atas. Hasil perhitungan regresi tersebut selanjutnya digunakan untuk menyusun persamaan regresi sebagai berikut.

$$
\begin{aligned}
\mathrm{Y}= & 4.553+0.183 \mathrm{X}_{1}-0.123 \mathrm{X}_{2}+ \\
& 0.465 \mathrm{X}_{3}+0.228 \mathrm{X}_{4}+\mathrm{e},
\end{aligned}
$$

Dari persamaan di atas dapat dijelaskan bahwa:

$$
\mathrm{a}=4.553 \text {, hasil analisi regresi nilai }
$$
konstantanya adalah 4.553, artinya nilai y sebesar 4.553 apabila variabel-variabel bebas lainnya adalah sama dengan nol atau konstan.

$\mathrm{b}_{1}=0.183$, merupakan koefisien variabel $\mathrm{X}_{1} \quad$ (pendidikan) terhadap jumlah upah artinya besarnya sumbangan yang diberikan variabel pendidikan terhadap upah pada industri kecil aaalah 
sebesar 0.183 dengan asumsi variabel bebas lainnya sama dengan nol atau konstan.

$b_{2}=-0.123$, merupakan koefisien variabel $\mathrm{X}_{2}$ (usia) terhadap jumlah upah artinya besarnya sumbangan yang diberikan variabel usia terhadap upah pada industri kecil adalah sebesar 0.123 dengan asumsi variabel bebas lainnya sama dengan nol atau konstan.

$\mathrm{b}_{3}=0.465$, merupakan koefisien variabel $\mathrm{X}_{3} \quad$ (lama kerja) terhadap jumlah upah artinya besarnya sumbangan yang diberikan variabel lama kerja terhadap upah pada industri kecil adalah sebesar 0.465 dengan asumsi variabel bebas lainnya sama dengan nol atau konstan.

$\mathrm{b}_{4}=0.228$, merupakan koefisien variabel $\mathrm{X}_{4}$ (beban tnggungan keluarga) terhadap jumlah upah artinya besarnya sumbangan yang diberikan variabel beban terhadap upah pada industri kecil adalah sebesar 0.228 dengan asumsi variabel bebas lainnya sama dengan nol atau konstan.

\section{Koefisien Korelasi (R)}

Adapun hasil perhitungan koefisien korelasi $(\mathrm{R})$ sebagaimana pada tabel analisis regresi dan model summary diperoleh nilai $\mathrm{R}$ $=0.945$, yang berarti bahwa terdapat keeratan hubungan antara variabel pendidikan, usia, lama kerja dan beban (X) dengan upah Kerja (Y) pada karyawan perusahaan rokok "Empat Saudara Abadi" sebesar 0.945, merupakan nilai positif yang mendekati hubungan yang sempurna; maka jika variabel pendidikan, usia, lama kerja dan beban (X) mengalami peningkatan setiap satu satuan unit maka Upah Kerja karyawan akan mengalami peningkatan satu satuan unit.

\section{Koefisien Determinasi $\left(\mathbf{R}^{\mathbf{2}}\right)$}

Adapun nilai koefisien determinasi sebagaimana pada label hasil analisis regresi dan model summary diperoleh nilia $\mathrm{R}$ square $\left(\mathrm{R}^{2}\right)=0.892$ atau $89.2 \%$, yang berarti bahwa besarnya pengaruh variabel pendidikan, usia, lama kerja dan beban $(\mathrm{X})$ terhadap upah kerja (Y) karyawan pada perusahaan rokok "Empat Saudara Abadi” adalah sebesar $89.2 \%$ 
sedangkan sisanya $\quad(11.8 \%)$

dipengaruhi oleh variabel lain yang dalam penelitian ini tidak diteliti/kaji.

\section{Uji Hipotesis}

a. Uji "F" (Uji simultan)

Sebagaimana ditunjukkan pada tabel ANOVA dan tabel hasil analisis regresi berganda, diperoleh nilai $F_{\text {hitung }}$ sebesar 93.301. Pengujian satu sisi pada $\alpha=0.05$ dan $\mathrm{df}_{1}=4$, dan $\mathrm{df}_{2}=$ 45 diperoleh nilai kritis atau nilai $F_{\text {tabel }}$ sebesar 2.58, sehingga dihasilkan $\mathrm{F}_{\text {hitung }}>\mathrm{F}_{\text {tabel }}(93.301$ > 2.58). Artinya $\mathrm{H}_{0}$ ditolak yang berarti secara simultan Pendidikan $\left(\mathrm{X}_{1}\right)$, Usia $\left(\mathrm{X}_{2}\right)$, Lama Kerja $\left(\mathrm{X}_{3}\right)$ dan Beban $\left(\mathrm{X}_{4}\right)$ memiliki pengaruh yang signifikan terhadap upah Kerja (Y) pada karyawan perusahaan rokok "Empat Saudara Abadi" kecamatan Baron-Nganjuk.

b. "t" (Uji Parsial)

Sebagaimana

ditunjukkan pada tabel hasil perhitungan regresi berganda yang menunjukkan bahwa :

Variabel Pendidikan $\left(\mathrm{X}_{1}\right)$, diperoleh nilai $t_{\text {hitung }}$ sebesar 3.333. Pengujian dua arah pada $\alpha / 2=0.05 / 2=0.025$ dan derajat bebas (df) $\mathrm{n}-1=49$, diperoleh nilai $t_{\text {tabel }}$ sebesar 2.000, sehingga dihasilkan $t_{\text {hitung }}>t_{\text {tabel }}$. Dengan demikian diputuskan bahwa $\mathrm{H}_{0}$ ditolak dan $\mathrm{H}_{1}$ diterima yang berarti bahwa variabel Pendidikan $\left(\mathrm{X}_{1}\right)$ berpengaruh terhadap variabel Upah kerja (Y). Apabila digambar pada distribusi t adalah sebagai berikut

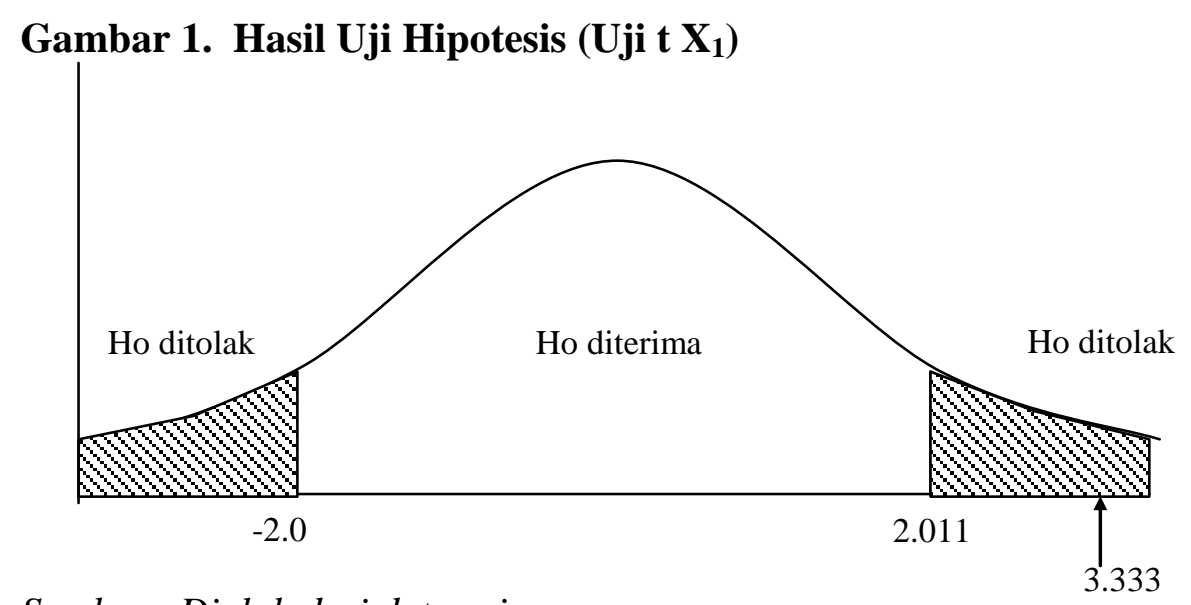

Sumber : Diolah dari data primer 
Variabel Usia $\left(\mathrm{X}_{2}\right)$, diperoleh nilai $t_{\text {hitung }}$ sebesar -1.783 . Pengujian dua arah pada $\alpha / 2=0.05 / 2=0.025$ dan derajat bebas $(\mathrm{df}) \mathrm{n}-1=49$, diperoleh nilai $t_{\text {tabel }}$ sebesar 2.000, sehingga dihasilkan $-t_{\text {hitung }}>-t_{\text {tabel }}$.
Dengan demikian diputuskan bahwa $\mathrm{H}_{0}$ diterima dan $\mathrm{H}_{1}$ ditolak yang berarti bahwa variabel Usia $\left(\mathrm{X}_{2}\right)$ tidak berpengaruh terhadap variabel Upah kerja (Y).

Apabila digambar pada distribusi $t$ adalah sebagai berikut:

\section{Gambar 2. Hasil Uji Hipotesis (Uji t $\mathbf{X}_{2)}$}

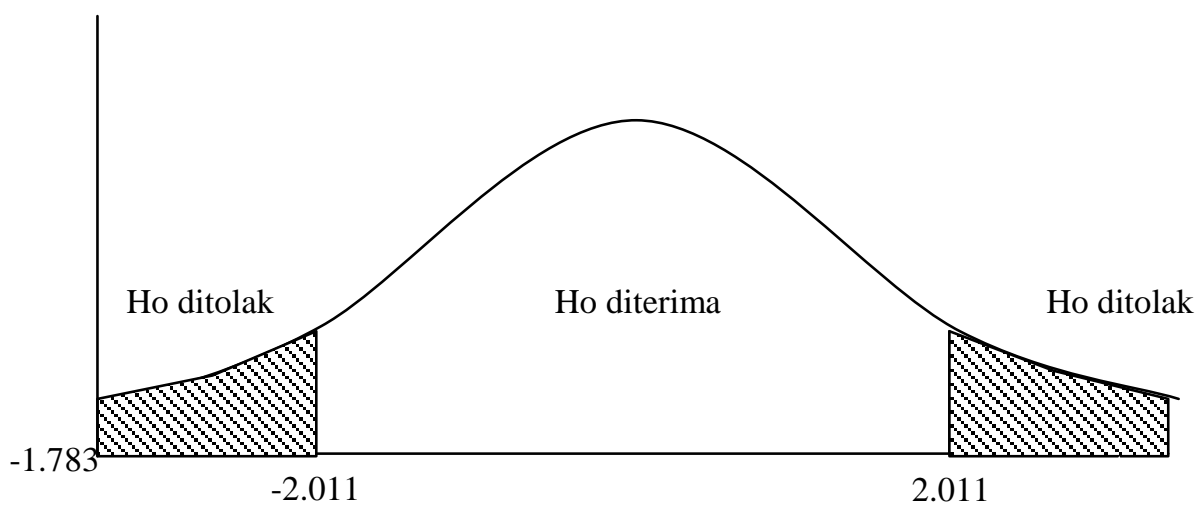

Sumber : Diolah dari data primer

Variabel Lama Kerja $\left(\mathrm{X}_{3}\right), \quad$ ditolak dan $\mathrm{H}_{1}$ diterima yang berarti diperoleh nilai $t_{\text {hitung }}$ sebesar 10.738 bahwa variabel Lama Kerja ( $\left.\mathrm{X}_{3}\right)$ Pengujian dua arah pada $\alpha / 2=0.05 / 2 \quad$ berpengaruh terhadap variabel Upah $=0.025$ dan derajat bebas $(\mathrm{df}) \mathrm{n}-1=$ 49, diperoleh nilai $\mathrm{t}_{\text {tabel }}$ sebesar 2.000, sehingga dihasilkan $t_{\text {hitung }}>t_{\text {tabel }}$. $\operatorname{kerja}(\mathrm{Y})$.

Apabila digambar pada distribusi t adalah sebagai berikut

Dengan demikian diputuskan bahwa $\mathrm{H}_{0}$

\section{Gambar 3. Hasil Uji Hipotesis (Uji t $\mathbf{X}_{3}$ )}

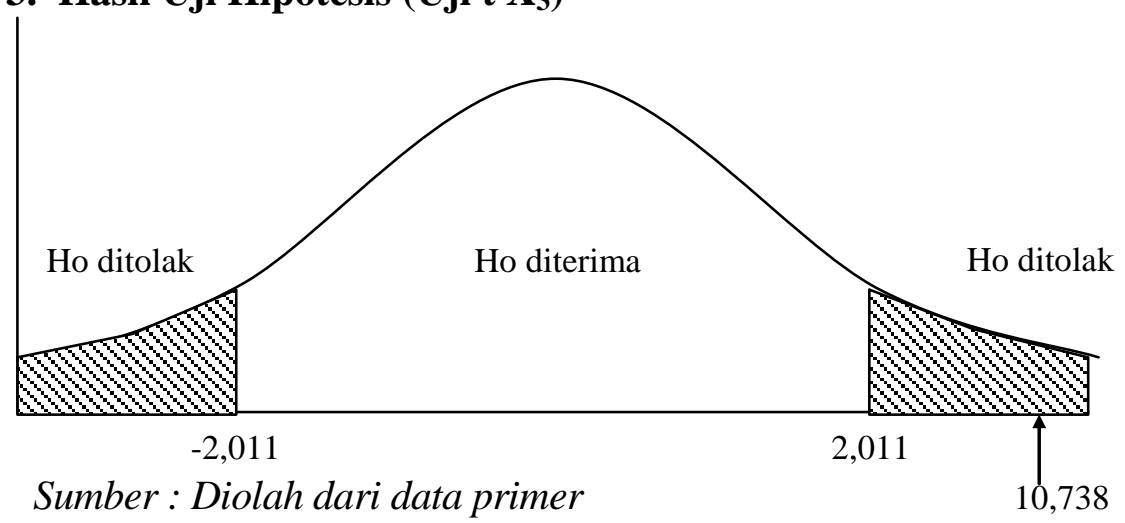


Variabel Beban $\left(\mathrm{X}_{4}\right)$, diperoleh

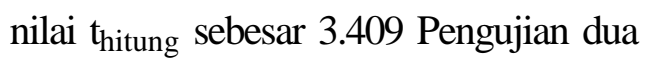
arah pada $\alpha / 2=0.05 / 2=0.025$ dan derajat bebas (df) $n-1=49$, diperoleh nilai $t_{\text {tabel }}$ sebesar 2.000, sehingga dihasilkan $t_{\text {hitung }}>t_{\text {tabel }}$.
Dengan demikian diputuskan bahwa $\mathrm{H}_{0}$ ditolak dan $\mathrm{H}_{1}$ diterima yang berarti bahwa variabel beban $\left(\mathrm{X}_{4}\right)$ berpengaruh terhadap variabel Upah $\operatorname{kerja}(\mathrm{Y})$.

Apabila digambar pada distribusi $\mathrm{t}$ adalah sebagai berikut:

\section{Gambar 4. Hasil Uji Hipotesis (Uji t $\mathbf{X}_{4}$ )}

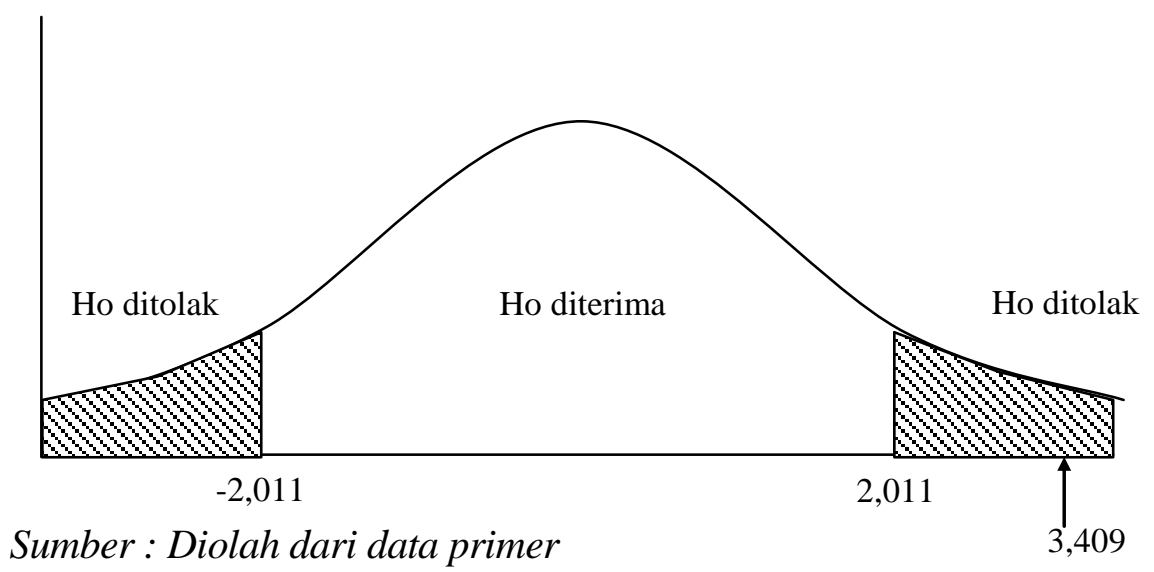

\section{Uji Asumsi Klasik}

\section{Uji Multikolonieritas}

Adapun tujuan dari uji multikolonieritas adalah untuk mengetahui apakah model regresi ditemukan adanya korelasi antar variabel bebas (independen). Untuk mendeteksi ada tidaknya multikolonieritas di dalam model regresi dapat dilakukan dengan menganalisis matrik korelasi antar variabel independen dan perhitungan nilai Tolerance dan VIF.

Berdasarkan hasil analisis regresi yang dilakukan, didapatkan hasil besaran korelasi varibel yang terbesar adalah korelasi antara variabel $\mathrm{X}_{3}$ dan variabel $\mathrm{X}_{4}$ yang mempunyai korelasi sebesar -0.662 atau sekitar $66.2 \%$. Oleh karena korelasi ini masih dibawah 95\%, maka dapat dikatakan tidak terjadi multikolonieritas yang serius.

Hasil perhitungan nilai Tolerance juga menunjukkan tidak ada variabel independen yang memiliki nilai Tolerance kurang dari 0.10 yang berarti tidak ada korelasi antar variabel independen yang nilainya lebih dari 95\%. Hasil VIF juga menunjukkan hal yang sama tidak ada satu variabel independen yang memiliki nilai VIF 
lebih dari 10. Jadi dapat disimpulkan bahwa tidak ada multikolonieritas antar variabel independen dalam model regresi pada penelitian in
Adapun tabel hasil pengujian multikolinier adalah sebagai berikut:

\section{Tabel 6. Hasil Uji Multikolinearitas}

\begin{tabular}{|c|c|c|c|}
\hline \multirow{2}{*}{ Variabel } & \multicolumn{2}{|c|}{ kolinieritas } & \multirow[t]{2}{*}{ Keterangan } \\
\hline & Tolerance & VIF & \\
\hline $\mathrm{X}$ & 0.841 & 1.190 & Tidak ada multikolinier \\
\hline $\mathrm{X}_{2}$ & 0.801 & 1.248 & Tidak ada multikolinier \\
\hline $\mathrm{X}_{3}$ & 0.541 & 1.829 & Tidak ada multikolinier \\
\hline $\mathrm{X}_{4}$ & 0.464 & 2.156 & Tidak ada multikolinier \\
\hline
\end{tabular}

Sumber : Diolah dari data primer

\section{Uji Autokorelasi}
Untuk mendeteksi ada tidaknya autokorelasi maka dilakukan dengan pengujian Durbin Watson (DW) dengan ketentuan sebagai berikut.

- 1,61 < DW <2,39, kesimpulannya tidak ada autokorelasi

- $1,21<\mathrm{DW}<1,61$ atau 2,39< DW $<2,79$, kesimpulannya tidak dapat disimpulkan (inconclusive)

- $\mathrm{DW}<1,21$ atau DW > 2,79, kesimpulannya terjadi autokorelasi

(Spyros Makridakis, Metode dan Apllkasi Peramalan, 1933) Berdasarkan hasil perhitungan didapatkan nilai Durbin Watson (DW) sebesar, 1,682. nilai ini menunjukkan bahwa nilai 1,682 berada pada kriteria pertama, yaitu
$1,61<1,682<2,38$ artinya dalam penelitian ini tidak terjadi autokorelasi.

\section{Uji Heteroskedastisitas}

Dari hasil deskripsi data yang disajikan dapat dijelaskan bahwa para pekerja wanita di perusahaan rokok "Empat Saudara Abadi" di Desa Jambi Kecamatan Baron Kabupaten Nganjuk. memiliki latar belakang pendidikan, tingkat usia, pengalaman kerja dan tanggungan/beban keluarga yang berbeda-beda.

Untuk tingkat pendidikan rata-rata pekerja wanita perusahaan rokok "Empat Saudara Abadi" di Desa Jambi Kecamatan Baron Kabupaten Nganjuk. didominasi oleh 
SLTP, sedangkan untuk usia ratarata didominasi oleh usia produktif yaitu antara 20-30 tahun, selanjutnya lama kerja yang dimiliki oleh para pekerja telah bekerja rata-rata 4-5 tahun. Dan untuk beban keluarga yang ditanggung rata-rata 3 orang. Dengan tingkat upah rata-rata sebesar $75.000-100.000$ ribu rupiah.

Dari analisis data yang dilakukan dapat dijelaskan bahwa terdapat pengaruh yang signifikan antara variabel bebas $(\mathrm{X})$ yang terdiri dari dari variabel pendidikan, usia, lama kerja dan beban terhadap varibel terikat (Y), upah kerja.

Hal ini memberikan gambaran bahwa keempat variabel tersebut mempengaruhi secara signifikan terhadap tingka upah para pekerja wanita pada perusahaan rokok "Empat Saudara Abadi" di Desa Jambi Kecamatan Baron Kabupaten Nganjuk.

Dalam penelitian ini selanjutnya yang dilakukan dengan analisis regresi memberikan penjelasan bahwa secara simultan, bersama-sama semua variabel bebas $\mathrm{X}$ berpengaruh secara signifikan terhadap variabel terikat $\mathrm{Y}$, dengan tingkat pengaruh sebesar $89,2 \%$, dengan tingkat keeratan hubungan antara variabel $\mathrm{X}$ dan $\mathrm{Y}$ adalah sebesar 0.945, dimana merupakan sebuah hubungan yang sangat kuat.

Berdasarkan hasil perhitungan terhadap uji t, dapat dijelaskan bahwa nilai $t$ hitung semua variabel jika dibandingkan dengan t-tabel maka thitung > t tabel kecuali untuk variabel $\mathrm{X}_{2}$, dimana $-\mathrm{t}$ hitung > -1 tabel, sehingga dapat dijelaskan secara parsial (masingmasing variabel), untuk variabei $\mathrm{X}_{1}$ (Pendidikan) memberikan pengaruh yang signifikan terhadap upah kerja, $\mathrm{X}_{2}$ (Upah) tidak memberikan pengaruh yang signifikan terhadap upah kerja, $\mathrm{X}_{3}$ (Lama kerja) memberikan pengaruh yang signifikan terhadap upah kerja dan $\mathrm{X}_{4}$ (Beban) memberikan pengaruh yang signifikan terhadap upah kerja.

Berdasarkan

hasil perhitungan $\mathrm{t}$ hitung dan koefisien regresi maka dapat diketahui bahwa variabel lama kerja $\left(\mathrm{X}_{3}\right)$ memiliki pengaruh yang paling dominan dibandingkan dengan variabel bebas lainnya.

\section{KESIMPULAN}

Dari hasil penelitian dan pembahasan mengenai profil tenaga 
kerja wanita yang di Perusahaan Rokok "EMPAT SAUDARA ABADI" berdasarkan tingkat pendidikan, tingkat upah, usia, lama bekerja, dan jumlah beban tanggungna keluarga, maka dapat di peroleh beberapa kesimpulan yaitu sebagai berikut:

Untuk tingkat pendidikan ratarata pekerja wanita perusahaan rokok "Empat Saudara Abadi” di Desa Jambi Kecamatan Baron Kabupaten Nganjuk. didominasi oleh SLTP yaitu sebanyak 19 orang atau 38\%, sedangkan untuk usia rata-rata didominasi oleh usia produktif yaitu antara 20-30 tahun sebanyak 38 orang atau $76 \%$, selanjutnya lama kerja yang dimiliki oleh para pekerja telah bekerja rata-rata 4-5 tahun sebanyak 22 atau 44\%. Dan untuk beban keluarga yang ditanggung rata-rata 3 orang sebanyak 20 orang atau $40 \%$. Dengan tingkat upah ratarata sebesar $75.000-100.000$ ribu rupiah yaitu sebanyak 25 orang atau $50 \%$.

Secara simultan semua variabel bebas (X) yang terdiri dari variabel pendidikan, usia, lama kerja dan beban memiliki pengaruh yang signifikan terhadap upah kerja karyawan perusahaan rokok "Empat Saudara Abadi” di Desa Jambi Kecamatan Baron Kabupaten Nganjuk.

Secara parsial, variabel bebas $\mathrm{X}$ yang terdiri dari variabel pendidikan, usia, lama kerja dan beban, masingmasing variabel memberikan pengaruh yang signifikan terhadap variabel upah kerja karyawan perusahaan rokok "EMPAT SAUDARA ABADI" di Desa Jambi Kecamatan Baron Kabupaten Nganjuk. kecuali variabel usia $X_{2}$, yang tidak memberikan pengaruh secara signifikan terhadap variabel upah kerja dari masing-masing koefisien regresi yang berarti juga pengujian pengaruh dari masing-masing variabel bebas terhadap variabel terikat. semakin usia bertambah semakin turun upah yang diterima permasalahan tersebut dikarenakan telah habisnya usia produktif menyebabkan menurunnya jumlah hasil kerja.

\section{DAFTAR PUSTAKA}

Keuangan. Abdullah M. Faisal. 2001. Dasar-dasar Manajemen Malang: UMM.

BR. Arfida. 2003. Ekonomi Sumber Daya Manusia. Malang: UMM. 
Gujarat, Damodar. 1991. Dasar

Ekonometrika. Jakarta:

Erlangga.

Kusrianto, Bambang. 1993. Meningkatkan Produktifitas Karyawan. Jakarta: PT Pustaka Binaman Persindo

Munandar, Utami SC. 1985. Emansipasi dan Peran Ganda Wanita Indonesia. Jakarta: Universitas Indonesia.

Masri, Singarimbun. 1995. Metode Penelitian Survei. Cetakan Kedua, Jakarta: Penerbit Pustaka LP3ES

Sasongko, Bambang. 2004. Teori Ekonomi Mikro. Cetakan Pertama. Penerbit: Universitas Negeri Malang

Simanjutak, Payaman J. 1998. Pengantar Sumber Daya Manusia. Jakarta: Fakultas Ekonomi UI
Sukirno, Sadono. 1994. Pengantar Ekonomi Mikro. Jakarta: PT. Raja Grafindo Persada

Sukirno, Sudono. 2000. Pengantar Teori Ekonomi Mikro. Jakarta: PT Raja Grafindo Persada

Wigati, Ningrum. Apri. 2000. Pengaruh Tingkat Upah terhadap pola Konsumsi Masyarakat di desa Japan Kec. sooko Kab. Mojokerto. Malang: UMM

Wahyudi. 2002. Hubungan Tingkat Pendidikan, Usia dan Jumlah Beban Tanggungan Keluarga Terhadap Tingkat Upah Ibu Rumah Tangga yang Bekerja di Sektor Pertanian di Desa SidoGedung Kec. Sengkapura Kab. Gresik. Malang:

UMM 